\title{
Ekotoxikologické zhodnocení ŕíčních sedimentů na vybraných lokalitách povodí řeky Odry
}

\section{ANTONÍN VONDRÁK, HANA SEZIMOVÁ, MARTIN MUCHA}

\author{
Klíčová slova: ekotoxikologie - sedimenty - povodí Odry - kontaminace - hydrochemie - legislativa - baterie \\ testů - potenciální nitrifikace - Sinapis alba - Folsomia candida - Lactuca sativa - Vibrio fischeri
}

\section{SOUHRN}

Př́spěvek se zabývá problematikou znečištění říčních (dnových) sedimentů v povodí řeky Odry, které se nachází na jednom z nejvíce antropogenně znečištěném území České republiky. Prezentované výsledky vycházejí ze zhodnocení říčních sedimentů odebraných na osmi vybraných profilech vodních útvarů, náležící do povodi řeky Odry, pomocí baterie pěti ekotoxikologických testů zahrnujících indikátorové organismy různých trofických úrovní. Ekotoxikologické hodnocení sedimentů bylo provedeno kontaktními testy a rovněž na vodných výluzích sedimentů pomocí akvatických testů. K detekci byl využit test na chvostoskocích Folsomia candida, test klícivosti a inhibice růstu na semenech Sinapis alba, test inhibice růstu na salátu Lactuca sativa, luminiscenční test na bakteriích Vibrio fischeri a stanovení potenciální nitrifikace a inhibice nitrifikace. Sledování byla doplněna kvantitativní analýzou majoritních a těžkých kovů ze stabilizovaných vodných výluhů vzorků dnových sedimentů pomocí metody atomové absorpční spektrometrie. $V$ rámci hodnocení byla porovnána citlivost jednotlivých testů a dále byla provedena analýza toxického zatížení sedimentů z jednotlivých sledovaných lokalit. Na základě dosažených výsledků Ize konstatovat, že sedimenty odebrané z Bohumínské stružky a řeky Lučiny vykazovaly nejvyšší toxické zatížení. Rovněž bylo potvrzeno, že vypovídající hodnota akvatických ekotoxikologických testů je velmi nízká a pro testování sedimentů je vhodné preferovat kontaktní ekotoxikologické testy.

\section{ÚVOD}

V říční síti České republiky dosahující v současnosti délky přibližně 33260 km je usazeno přibližně $5 \times 10^{6} \mathrm{~m}^{3}$ sedimentu, v němž se akumuluje většina z 20 prioritních nebezpečných látek, ale také množství dalších nebezpečných látek anorganické i organické povahy. Kontaminovány jsou především úseky toků vyskytující se v oblastech se zvýšenou průmyslovou a zemědělskou činností $[1,2]$. Součástí zhodnocení stavu útvarů povrchových vod a kvality povrchových vod jsou rovněž informace o kvalitě a množství pevných složek vodního ekosystému, kterými jsou plaveniny a dnové sedimenty. Analýzy dnových sedimentů poskytují na rozdíl od analýz vody komplexnější informaci o výskytu kontaminantů s akumulačním potenciálem ve sledovaném toku [1].

Kontaminace dnového sedimentu je úzce spjata se znečištěním vody daného říčního toku. $V$ závislosti na hydrologických podmínkách a morfologii řeky se mohou suspendované částice usadit a stát se tak součástí dnových sedimentů, často mnoho kilometrů za zdrojem původního znečištění [3]. Velký povrch minerálních částic přitomných v sedimentu je důležitý převážně pro navázání elektricky nabitých polutantů, a to především kationtů těžkých kovů (např. arsen, kadmium, chrom, měd', nikl, rtut', olovo, zinek a mangan) [4]. Sorpce je umožněna díky vazbě záporného náboje vyskytujícího se na povrchu většiny prírodních minerálů sedimentu s kladně nabitými kationty těžkých kovů [5]. Mezi látky schopné sorpce těžkých kovů patří hydratované hlinitokřemičitany (jíly), hydratované oxidy, křemičitany, uhličitany a fosforečnany [6]. Nezastupitelnou roli při sorpci těžkých kovư má také velikost jednotlivých částic minerálních látek tvořících říční sediment [5]. Ve vodních tocích dosahují minerální částice značného rozsahu velikostí, a to od $\leq 0,004 \mathrm{~mm}$ u jílovitých frakcí až po balvany o velikosti $\geq 256 \mathrm{~mm}$ [7]. Frakce sedimentu o velikosti částic $<0,1$ mm dokáže díky svému specifickému povrchu navázat vyšší koncentrace těžkých kovů, než frakce obsahující částice větších rozměrů [5]. Prủběh sorpčních procesů je rovněž úzce ovlivňován hodnotami pH prostředí. Se snížením hodnot pH jsou kationty těžkých kovů desorbovány z povrchu částic sedimentu a následně jsou uvolněny do vodné fáze, odkud se mohou vlivem průtoku daného toku transportovat do dalších lokalit dále po proudu [8]. Nebezpečnost znečištění sedimentů těžkými kovy spočívá nejen v jejich toxickém působení na živé organismy, ale také ve velmi lehké schopnosti akumulace. Kovy z antropogenních zdrojů se nacházejí především v nestálých frakcích sedimentů. Odtud mohou být vstřebávány organismy, dále se dostávat přes jednotlivé trofické úrovně do dalších částí potravního řetězce $[9,10]$, a znamenat tak riziko pro široké spektrum organismů.

Velká plocha povrchu nejjemnějších částic tvořících sediment se zároveň uplatňuje při vazbě elektroneutrálních polutantů, jejichž největší zastoupení představují perzistentní organické látky (POPs), a to díky jejich hydrofobnímu charakteru [11]. Hydrofobnost je vlastnost důležitá pro zachycování některých nepolárních organických polutantů, jako jsou např. ropné látky (NEL), některé pesticidy a jejich rezidua, polycyklické aromatické uhlovodíky (PAU), polychlorované bifenyly $(\mathrm{PCB})$, adsorbovatelné organické halogeny (AOX) a dalši podobné látky [12]. Vliv skokových změn hodnot pH na desorpci organických látek z částic sedimentu není tak markantní, jako je tomu u kationtů těžkých kovů. Výjimkou jsou ionizovatelné organické molekuly, které se podobně jako kationty těžkých kovů mohou adsorbovat na povrch částic sedimentu [13]. Zásadní vliv na desorpci organických látek navázaných na organickou hmotu tvořicí sediment představují ve vodě rozpuštěné organické látky. Uvádí se, že vysoké koncentrace rozpuštěného organického uhlíku v povrchové vodě mohou výrazně ovlivňovat desorpci toxických látek (např. PCB, PAU) navázaných na sediment [14].

Zpráva o stavu vodního hospodářství České republiky v roce 2018 [15] vydaná MZe ČR uvádí, že sedimenty a plaveniny dílčího povodí horní Odry jsou dlouhodobě znečištěny zejména polyaromatickými uhlovodíky (benzo(a)pyrenem, benzo(b)fluorantenem, benzo(g,h,i) perylenem, benzo(k)fluorantenem a indeno(1,2,3-cd)pyrenem). Kontaminace sedimentu těmito látkami 
souvisí pravděpodobně s dlouhodobou atmosférickou depozicí produktů spalování fosilních paliv z průmyslových zdrojů, lokálních topeništ a dopravy $\checkmark$ regionu povodí a splachy z kontaminovaných ploch. Rovněž Hydrologická ročenka České republiky 2017 [1] vydaná ČHMÚ shodně uvádí, že pro dílčí oblast povodí horní Odry jsou na většině sledovaných profilů charakteristické nadlimitní obsahy polyaromatických uhlovodíků v sedimentu (antracen, fluoranten a suma 5 PAU). Nejvyšší koncentrace byly naměřeny $\vee$ sedimentech získaných z řeky Odry v Bohumíně pod ostravskou průmyslovou aglomerací. Z hlediska míry znečištění byl jako nadlimitní se vzrůstajícím trendem vyhodnocen obsah olova a fluorantenu v plaveninách a sedimentu řeky Ostravice v Ostravě.

Obecně se doporučuje, aby se toxicita říčního sedimentu stanovovala komplexně pomocí chemické analýzy a současně biologickými testy, tedy i jako biologická odpověd’ organismu na expozici škodlivými látkami. Testovací organismus vystavený účinkům kontaminovaného sedimentu umožňuje stanovit účinky chemických látek adsorbovaných na dnový sediment [16]. Bláha [17] uvádí, že ekotoxikologické testy dnových sedimentů mají své využití nejen v oblasti aplikace na zemědělskou půdu podle vyhlášky č. 257/2009 Sb., ale také při ověřování škodlivosti látek či směsí pro vodní organismy, škodlivosti odpadů ve vztahu ke stanovované nebezpečné vlastnosti Ekotoxicita (HP14), prrípustnosti využití odpadních zemin a stavebních sutí k terénním úpravám a rekultivacím a stavu testované matrice formou nezávislých testů (testy nezávislé na rozsahu limitních hodnot chemických polutantů zakotvených v legislativě). $\checkmark$ legislativě České republiky je zakotveno hned několik základních ekotoxikologických testů standardně využívaných při hodnocení kvality půdy a dnových sedimentů. Jedná se o vyhlášku č. 257/2009 Sb., o používání sedimentů na zemědělské půdě, dále vyhlášku č. 94/2016 Sb., o hodnocení nebezpečných vlastností odpadů a vyhlášku č. 294/2005 Sb., o podmínkách ukládání odpadů na skládky a jejich využívání na povrchu terénu. Dále existuje široké spektrum variant doplňkových ekotoxikologických testů používaných v ČR, které již nejsou zakotveny v legislativě, ale množství laboratoří je používá jako doplňkové pro zpřesnění a validaci naměřených výsledků.

Predkládaný přispěvek je zaměřen na hodnocení toxického působení dnových sedimentů odebraných z vodních toků povodí řeky Odry na živé organismy a rovněž ověrení vhodnosti využití kombinace vybrané baterie biologických testů zahrnující organismy různých trofických úrovní pro sledováni ekotoxických účinků dnových sedimentů. Pro komplexnější zhodnocení sedimentů byla detekce toxických vlivů na živé organismy doplněna kvantitativní analýzou majoritních a těžkých kovů ze stabilizovaných vodných výluhů vzorků dnových sedimentů pomocí metody atomové absorpční spektrometrie.

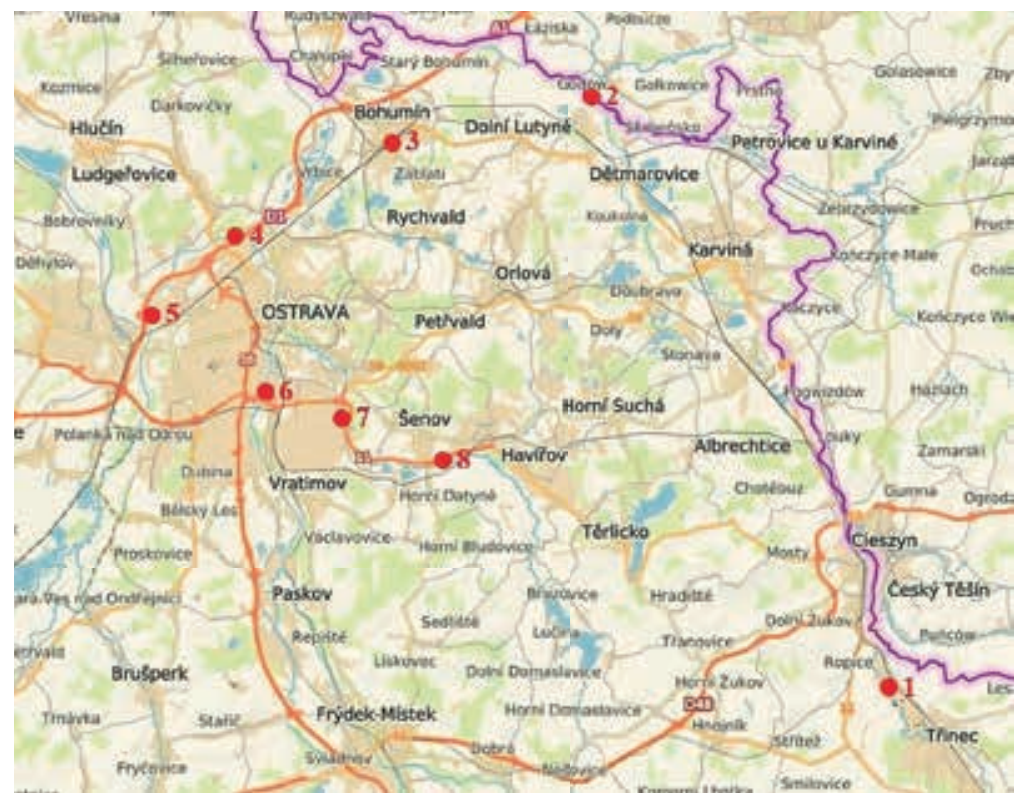

Obr. 1. Mapa odběrných míst sedimentů, legenda vyznačených lokalit, viz tabulka 1 (zdroj: https://www.openstreetmap.org/)

Fig. 1. Map of sediment sampling points, legend of marked localities see Table 1 (source: https://www.openstreetmap.org/)

\section{MATERIÁLY A METODY}

\section{Výběr toků pro odběr sedimentů}

Výběr lokalit pro odběr dnových sedimentů byl proveden na základě výskytu aktivní průmyslové činnosti v okolí sledovaného toku, poprípadě byly zohledňovány lokality se starou ekologickou zátěží po již ukončené těžbě či průmyslové výrobě. Vybrané lokality jsou graficky znázorněny v mapě (obr. 1). Jako legenda k mapě slouží tabulka 1, v níž jsou zaznamenány jednotlivé toky a lokalizace míst, na nichž byly odběry provedeny, včetně polohy GPS.

Tabulka 1. Přehled odběrných míst dnových sedimentů Table 1. Overview of bottom sediment sampling points

\begin{tabular}{llll} 
Č́slo profilu & Název toku & Lokalita & GPS souřadnice \\
\hline 1 & Olše & Třinec, železárny & $49^{\circ} 42^{\prime} 02.4^{\prime \prime} \mathrm{N} 18^{\circ} 38^{\prime} 13.1^{\prime \prime} \mathrm{E}$ \\
\hline 2 & Olše & Dětmarovice, elektrárna & $49^{\circ} 55^{\prime} 04.6^{\prime \prime} \mathrm{N} 18^{\circ} 27^{\prime} 55.3^{\prime \prime} \mathrm{E}$ \\
\hline 3 & Bohumínská stružka & Nový Bohumín, nádraží & $49^{\circ} 54^{\prime} 17.4^{\prime \prime} \mathrm{N} 18^{\circ} 22^{\prime} 05.2^{\prime \prime} \mathrm{E}$ \\
\hline 4 & Černý potok & Ostrava - Př́ívoz, zaústění Odra & $49^{\circ} 51^{\prime} 45.8^{\prime \prime} \mathrm{N} 18^{\circ} 15^{\prime} 56.7^{\prime \prime} \mathrm{E}$ \\
\hline 5 & Opava & Ostrava - Třebovice, zaústění Odra & $49^{\circ} 49^{\prime} 59.1^{\prime \prime} \mathrm{N} 18^{\circ} 13^{\prime} 13.4^{\prime \prime} \mathrm{E}$ \\
\hline 7 & Ostravice & Ostrava - Kunčice, Dolní oblast Vítkovic & $49^{\circ} 48^{\prime} 19.7^{\prime \prime} \mathrm{N} 18^{\circ} 17^{\prime} 03.1^{\prime \prime} \mathrm{E}$ \\
\hline 8 & Lučina & Ostrava - Kunčice, Nová Hut Zářičí & $49^{\circ} 48^{\prime} 00.0^{\prime \prime} \mathrm{N} 18^{\circ} 19^{\prime} 46.0^{\prime \prime} \mathrm{E}$ \\
\hline
\end{tabular}



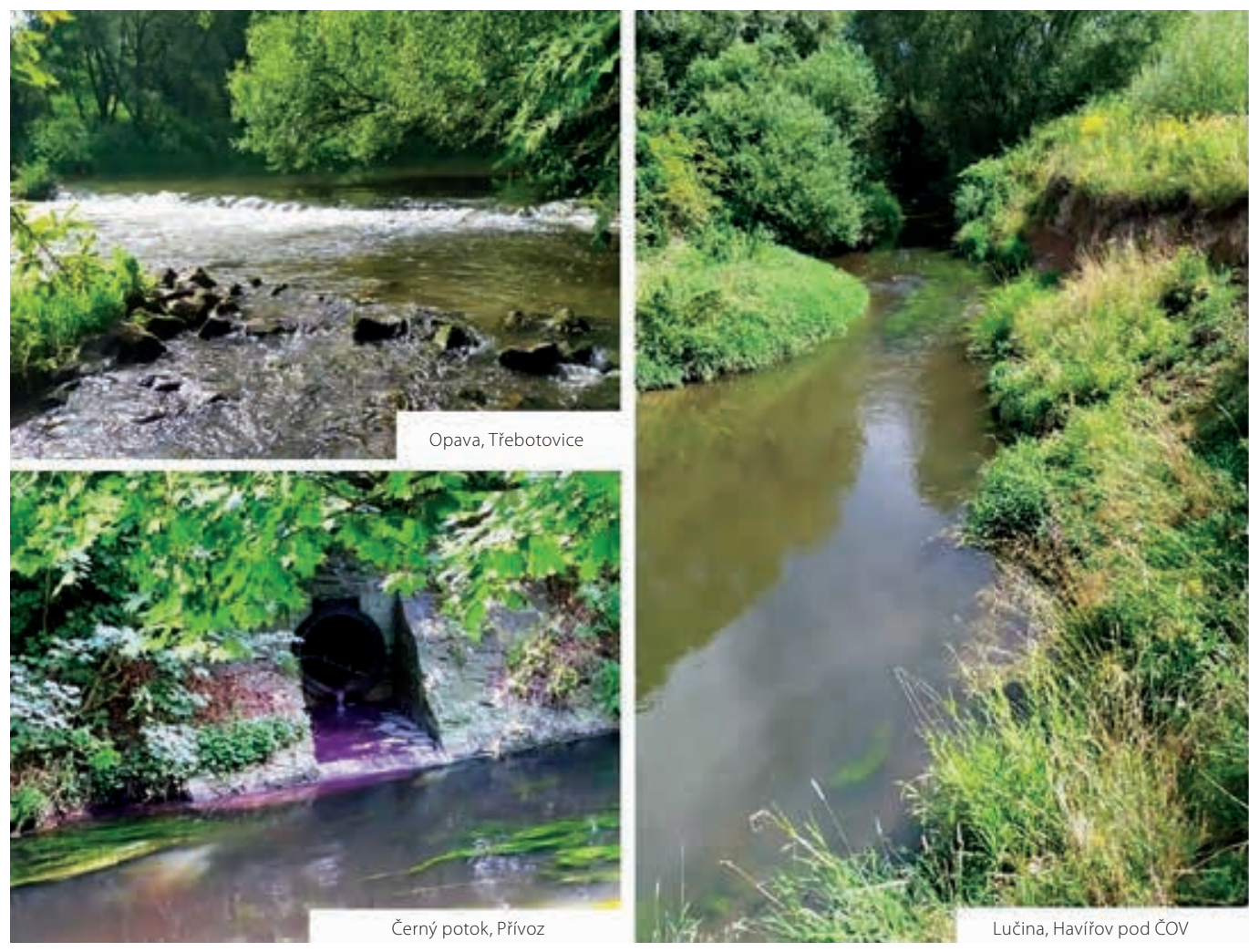

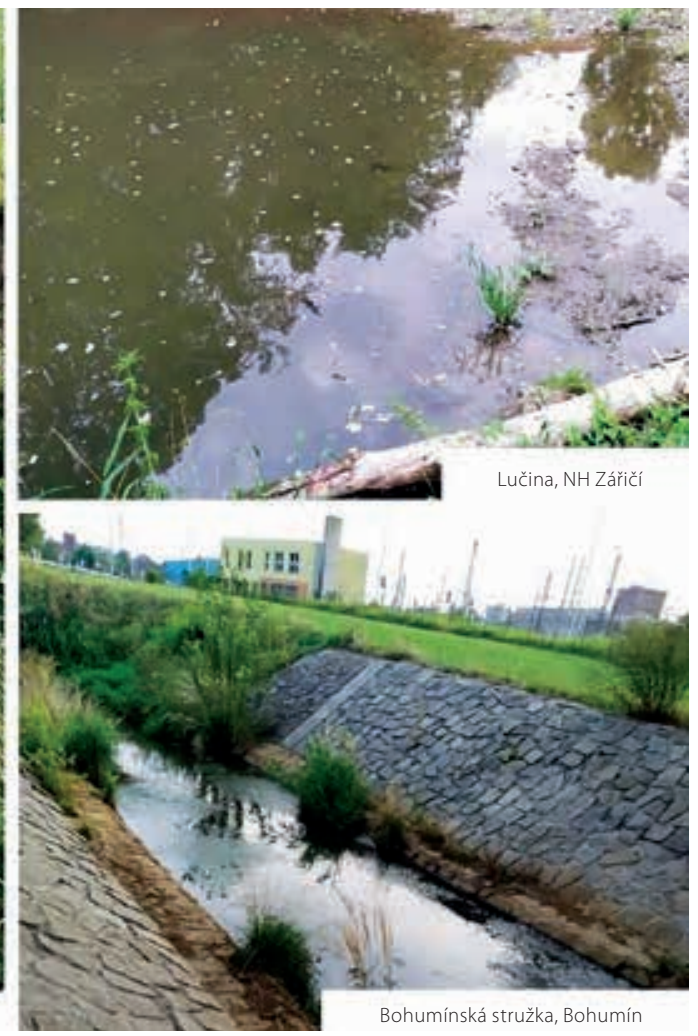

Obr. 2. Fotografie vybraných lokalit odběru

Fig. 2. Images of selected sampling sites

\section{Odběr a príprava sedimentů}

Vzorky dnových sedimentů byly odebírány na osmi profilech šesti toků v rámci povodí řeky Odry (obr. 2). Vzorkování bylo prováděno v souladu s ČSN ISO 5667-12 [18]. Na každé z uvedených lokalit byl pomocí nerezové lopatky odebírán směsný vzorek dnového sedimentu o celkové hmotnosti $10 \mathrm{~kg}$. Odběr byl na každém profilu realizován na čtyřech místech napříc korytem z hloubky $10-15 \mathrm{~cm}$, kdy místa odběru byla od sebe vzdálena 0,25-1 m, v závislosti na širrce koryta. Odebraný materiál byl uložen do plastové nádoby a následně byl transportován do laboratoře, kde se po dobu 2-4 týdnů v závislosti na struktuře a zrnitosti materiálu pozvolna vysoušel na plastových tácech při laboratorní teplotě. Po úplném vysušení byl každý vzorek proséván přes síto o velikosti průměru ok $2 \mathrm{~mm}$ s deklarovanou inertností vhodnou pro stanovení těžkých kovů a akutní toxicity. U prosetých vzorkủ byla stanovena hodnota pH podle ČSN ISO 10390 [19] a WHC půdy podle ČSN ISO 11274 [20]. Pro potřeby povedení zkoušek na semenech Sinapis alba a bakteriích Vibrio fischeri a rovněž pro chemickou analýzu vybraných kovů pomocí atomové absorpční spektrometrie (AAS) byly připraveny vodné výluhy vzorků sedimentů podle normy ČSN EN 12457-4 [21]. Před provedením AAS byly všechny vzorky filtrovány pres membránové filtry Pragopor 6 (póry < 0,4 um) k eliminaci zákalu způsobeného prítomností jílových minerálů a byly stabilizovány prídavkem kyseliny dusičné.

\section{Chemická analýza vybraných kovů}

Stanovení iontů kovů bylo provedeno metodou atomové absorpční spektrometrie (AAS). Pro stanovení iontů $\mathrm{Ca}, \mathrm{Mg}, \mathrm{Fe}, \mathrm{K}, \mathrm{Na}$ a $\mathrm{Zn}$ byla použita plamenová atomizace se vzduch-acetylénovým plamenem na prístroji Varian AA240

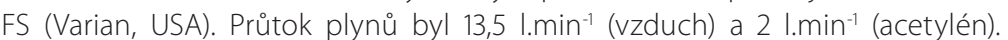

Stanovení bylo provedeno při vlnových délkách 422,7 nm (Ca), 202,6nm (Mg), 372,0 nm (Fe), 404,4 nm (K), 330,3 nm (Na) a 213,9 nm (Zn). Ionty Pb, Cd a Cr byly stanoveny metodou AAS s elektrotermickou atomizací na prístroji Agilent $240 Z$ AA s grafitovou píckou Agilent GTA120 (Agilent technologies, USA). Stanovení Pb probíhalo při vinové délce 283,3 nm a jako modifikátor ( $v$ režimu co-inject) byl použit dihydrogenfosforečnan amonný. Stanovení Cd bylo realizováno při vlnové délce $228,8 \mathrm{~nm}$ a stanovení Cr při vlnové délce $357,9 \mathrm{~nm}$. Při stanovení $\mathrm{Cd}$ a Cr nebyl použit modifikátor. Obsah iontů rtuti byl stanoven metodou studených par (CV AAS) na př́stroji Varian AA240FS s jednotkou generátoru studených par VGA77 (Agilent technologies, USA). Pro prípravu všech kalibračních roztoků byly použity standardy jednotlivých iontů (Sigma-Aldrich s. r. o., Česká republika).

\section{Test akutní toxicity na semenech hořčice bílé (Sinapis alba)}

Test na semenech hořčice bílé byl proveden podle Metodického pokynu odboru odpadů ke stanovení ekotoxicity odpadů MŽP ČR [22]. Hodnoceny byly vodné výluhy vzorků sedimentů bez použití koncentrační řady vzniklé ředěním. Součástí testu byla negativní a pozitivní kontrola s využitím standardní látky dichromanu draselného (100 mg. $\left.{ }^{-1}\right)$. Test byl prováděn ve skleněných Petriho miskách o průměru $150 \mathrm{~mm}$ ve třech paralelních opakováních. Z každého vodného výluhu vzorku bylo na povrch filtračního papíru v Petriho misce napipetováno $5 \mathrm{ml}$. Poté bylo na zvlhčený filtrační papír rozmístěno celkem 30 semen hořčice bílé. Inkubace probíhala v termostatu bez přístupu světla po dobu $72 \pm 2$ hodin, při teplotě $20 \pm 2{ }^{\circ} \mathrm{C}$. Sledovaným parametrem testu byla průměrná délka kořenů semen hořčice bílé po 72 hodinách, ze které byla vypočitána inhibice růstu. 


\section{Test akutní toxicity na bakterii Vibrio fischeri}

Pro zjištění akutní toxicity vzorků vodných výluhů vzorků sedimentů byl proveden luminiscenční test na bakteriích Vibrio fischeri podle ČSN EN ISO 11348-1 [23]. Součástí každého testu byla negativní a pozitivní kontrola s využitím standardní látky dichromanu draselného (0,4-100 mg. $\left.\mathrm{I}^{-1}\right)$. Měření inhibice luminiscence bylo prováděno po 15 a 30minutové expozici pomocí luminometru s měřící celou temperovanou na $15 \pm 1{ }^{\circ} \mathrm{C}$ (LUMIStox, Hach-Lange GmbH). Z výsledků testů inhibice luminiscence byly vypočítány hodnoty inhibice emise světla u bakterii Vibrio fischeri v porovnání s kontrolou.

\section{Test akutní toxicity na chvostoskocích (Folsomia candida)}

Test pro stanovení mortality a inhibice reprodukce chvostoskoků (Folsomia candida) byl proveden podle ČSN EN ISO 11267 [24]. Principem testu bylo procentuální stanovení mortality a inhibice reprodukce chvostoskoků (Folsomia candida) po 28denní expozici ve vzorcích sedimentů, nebo ve směsi artificiální půdy s koncentrační řadou ověřované standardní látky. Test byl prováděn ve skleněných nádobách s pevným uzávěrem ve třech paralelních opakováních. Do každé nádoby bylo naváženo $30 \mathrm{~g}$ suchých vzorků dnových sedimentů, které byly následně zvlhčeny destilovanou vodou na hodnotu $50 \% \mathrm{WHC}_{\max }$. Poté bylo na povrch zvlhčeného substrátu pomocí dechového exhaustoru umístěno 10 jedinců Folsomia candida ze synchronizované kultury. Inkubace probíhala v termostatu bez prístupu světla po dobu 28 dní, při teplotě $20 \pm 2{ }^{\circ} \mathrm{C}$. $\checkmark$ průběhu inkubace byla zajištěna aerace, potrava a byl kontrolován výpar vody. Po uplynutí doby expozice se obsah jednotlivých sklenic prevedl do Petriho misky o průměru 150 mm. Po obarvení kontrastní látkou (černá tuš, popř. modrý inkoust) byla po vyfotografování digitálním fotoaparátem s vysokým rozlišením provedena analýza v programu ImageJ. Sledovaným parametrem testu byl počet adultních a juvenilních jedinců. Na základě získaných hodnot bylo vypočitáno procento mortality adultních jedinců a procento průměrné inhibice reprodukce.

\section{Test pro stanovení potenciální nitrifikace - mikrometoda}

Mikrometoda testu pro stanovení potenciální nitrifikace byla provedena podle ČSN ISO 15685 [25]. Pro každý vzorek sedimentu byly připraveny čtyři polyethylenové zkumavky o objemu $50 \mathrm{ml}$. Do zkumavky bylo naváženo 2,5 g vzorku a přidáno $10 \mathrm{ml}$ zkušebního média. Zkumavky byly umístěny do orbitální třepačky
(Rotamax 120, Heidolph Instruments GmbH \& CO. KG, Německo) s rychlostí otáčení 175 ot.min ${ }^{-1}$, kde se inkubovaly při laboratorní teplotě po dobu 2 h a 6 h. Následně byl z každé zkumavky odebrán $1 \mathrm{ml}$ vzorku do zkumavek $\mathrm{s} 1 \mathrm{ml}$ roztoku $\mathrm{KCl}\left(c=4\right.$ mol. $\left.^{-1}\right)$ a po inkubaci (20 minut) byly vzorky centrifugovány (MR23i, Thermo Fisher Scientific Inc., USA) při $3000 \mathrm{~g}$ po dobu 2 minut. U vzniklého supernatantu bylo provedeno spektrofotometrické stanovení množství dusitanů na mikrotitrační destičce (Epoch, BioTek Inc., USA) při vInové délce $\lambda=540 \pm 10 \mathrm{~nm}$. Naměřené hodnoty byly vyhodnoceny prostřednictvím softwaru Gen5 ${ }^{\mathrm{TM}}$ ver. 1.11 .

\section{Test akutní toxicity na semenech lociky seté (Lactuca sativa)}

Test na předklíčených semenech salátu lociky seté (Lactuca sativa) byl proveden podle SOILETOX-SOP-20 [26]. Do transparentních testovacích nádob ve 3 paralelních stanoveních bylo naváženo 155 g suchých reálných vzorků dnových sedimentů, které byly následně zvlhčeny destilovanou vodou na hodnotu $70 \% \mathrm{WHC}_{\max }$. Jako negativní kontrola sloužila artificiální půda. Poté bylo do každé nádoby rozmístěno 15 předklíčených semen salátu. Nádoby byly uzavřeny víkem a umístěny do termostatu (MIR-154, Sanyo, Japonsko) s nastavenou teplotou $24^{\circ} \mathrm{C}$, bez prístupu světla. Po $120 \mathrm{~h}$ inkubace byly změřeny délky kořenů všech semen s přesností na $1 \mathrm{~mm}$. Naměřená data byla poté zpracována pro výpočet procenta inhibice růstu kořenů Lactuca sativa.

\section{VÝSLEDKY A DISKUSE}

V rámci hodnocení vzorků dnových sedimentů z vybraných vodních útvarů povodí řeky Odry bylo provedeno stanovení hodnoty $\mathrm{pH}$ sedimentů a jejich vodných výluhů a rovněž byla stanovena WHC reálných vzorků sedimentů. Hodnota pH u vzorků sedimentů z jednotlivých lokalit se pohybovala v rozmezí 6,46-7,79, vodné výluhy sedimentů vykazovaly podobné hodnoty v intervalu 6,57-7,70. Vodní kapacita WHC byla u většiny vzorků v rozmezí 0,305-0,455 ml.g-1 sedimentu, pouze u vzorku sedimentu odebraného z Bohumínské stružky v profilu Nový Bohumín byl naměěena vyšší hodnota $\left(0,872 \mathrm{ml} \cdot \mathrm{g}^{-1}\right)$.

Tabulka 2. Naměrené koncentrace majoritnich kovi̊ ve vzorcích

Table 2. Measured concentrations of major metals in samples

\begin{tabular}{|c|c|c|c|c|c|}
\hline Vzorek & $\mathrm{Ca}\left(\mathrm{mg} \cdot \mathrm{I}^{-1}\right)$ & $\operatorname{Mg}\left(\mathrm{mg} \cdot \mathrm{I}^{-1}\right)$ & $\mathrm{Fe}\left(\mathrm{mg} \cdot \mathrm{I}^{-1}\right)$ & $\mathrm{Na}\left(\mathrm{mg} \cdot \mathrm{I}^{-1}\right)$ & $\mathrm{K}\left(\mathrm{mg} \cdot \mathrm{I}^{-1}\right)$ \\
\hline Olše, Třinec & $20,57 \pm 0,09$ & $2,67 \pm 0,04$ & $1,61 \pm 0,25$ & $<6,30$ & $<4,98$ \\
\hline Olše, Dětmarovice & $30,77 \pm 0,03$ & $1,86 \pm 0,01$ & $1,22 \pm 0,38$ & $<6,30$ & $<4,98$ \\
\hline Bohumínská stružka, N. Bohumín & $184,95 \pm 0,63$ & $6,53 \pm 0,01$ & $6,84 \pm 3,50$ & $88,7 \pm 27,3$ & $31,1 \pm 0,7$ \\
\hline Černý potok, O. - Přívoz & $30,22 \pm 0,27$ & $4,96 \pm 0,06$ & $2,04 \pm 0,35$ & $12,1 \pm 4,7$ & $<4,98$ \\
\hline Opava, O. - Třebovice & $10,25 \pm 0,07$ & $1,76 \pm 0,02$ & $1,28 \pm 0,24$ & $<6,30$ & $<4,98$ \\
\hline Ostravice, O. - Vítkovice DOV & $25,34 \pm 0,17$ & $2,36 \pm 0,03$ & $1,18 \pm 0,15$ & $<6,30$ & $<4,98$ \\
\hline Lučina, O. - Kunčice NH Zářičí & $10,22 \pm 0,08$ & $1,15 \pm 0,01$ & $2,27 \pm 0,18$ & $<6,30$ & $<4,98$ \\
\hline Lučina, Haviŕov pod ČOV & $18,34 \pm 0,10$ & $3,15 \pm 0,02$ & $2,31 \pm 0,50$ & $<6,30$ & $<4,98$ \\
\hline
\end{tabular}




\section{AAS analýza}

Výsledky stanovení rozpuštěných iontů kovů ve výluzích jednotlivých vzorků jsou uvedeny $v$ tabulce 2. Z pohledu obsahů majoritních iontů ( $\mathrm{Ca}, \mathrm{Mg}$, Fe, $\mathrm{Na}$ a K) se značně odlišuje vzorek z Bohumínské stružky, který vykazuje násobně vyšší obsahy Ca, Na a K v porovnání s ostatními vzorky. Zvýšený obsah těchto iontů $\checkmark$ Bohumínské stužce je pravděpodobně zpưsoben vypouštěním slaných důlních vod z vodní jámy Žofie v Orlové [27] a Heřmanického rybníku [26] a může přispívat k vyšší ekotoxikologické zátěži způsobované sedimentem z této lokality.

Obsahy iontů těžkých kovů ve výluzích sedimentů jsou uvedeny v tabulce 3. Zjištěné hodnoty obsahů iontů těžkých kovů jsou u všech zkoumaných vzorků výluhů sedimentů velmi nízké, často pod limitem kvantifikace použité analytické metody. Lze konstatovat, že žádná z naměřených hodnot nepřekračuje prípustné hodnoty stanovené nařízením vlády č. 401/2015 Sb. [28]. S výjimkou obsahu Pb splňují výluhy i požadavky kladené na pitnou vodu z pohledu obsahu zkoumaných iontů těžkých kovů dané vyhláškou č. 70/2018 Sb. [29]. lonty těžkých kovů tedy pravděpodobně nepředstavují u zkoumaných sedimentů rizikový faktor.

\section{Statistické hodnocení}

Pro jednotlivé sledované parametry byla provedena statistická analýza zahrnující test na normalitu dat (Shapiro-Wilk test), test pro analýzu variance (ANOVA) a test pro mnohonásobné porovnávání (Tukey test). Na základě Shapiro-Wilk testu bylo zjištěno, že všechna naměěená data pocházejí z normálního rozdělení. Test pro analýzu variance (ANOVA) jednotlivých metod potvrzuje, že vzorky dnových sedimentů signifikantně ovlivňují sledovaný negativní účinek. Mortalita Folsomia candida $(F=4,845 ; P$-value $=0,0026)$, inhibice reprodukce Folsomia candida ( $F=5,618$; $P$-value $=0,0012)$, potenciální nitrifikace $(F=644,3$; $P$-value $<0,0001)$, inhibice růstu kořene Lactuca sativa ( $F=11,73$; $P$-value $<0,0001)$, inhibice luminiscence Vibrio fischeri $(F=6,007$; $P$-value $=0,0002)$. Výsledky Tukey testu jsou uvedeny $v$ textu u výsledků jednotlivých zkoušek $v$ rámci ekotoxikologického hodnocení.

Tabulka 3. Naměrené koncentrace iontů těžkých kovů ve vzorcích

Table 3. Measured concentrations of heavy metal ions in samples

\begin{tabular}{|c|c|c|c|c|c|}
\hline Vzorek & $\mathrm{Pb}\left(\boldsymbol{\mu g} \cdot \mathrm{I}^{-1}\right)$ & $\operatorname{Cd}\left(\mu \mathrm{g} . \mathrm{I}^{-1}\right)$ & $\operatorname{Cr}\left(\mu \mathrm{g} . \mathrm{I}^{-1}\right)$ & $\operatorname{Zn}\left(\boldsymbol{\mu g} . I^{-1}\right)$ & $\mathrm{Hg}\left(\mu \mathrm{g} . \mathrm{I}^{-1}\right)$ \\
\hline Olše, Třinec & $34,73 \pm 0,67$ & $0,737 \pm 0,025$ & $4,81 \pm 0,53$ & $133,3 \pm 2,7$ & $<0,25$ \\
\hline Olše, Dětmarovice & $<12,5$ & $0,281 \pm 0,009$ & $<1,36$ & $43,3 \pm 0,8$ & $<0,25$ \\
\hline Bohumínská stružka, N. Bohumín & $<12,5$ & $0,136 \pm 0,011$ & $<1,36$ & $73,0 \pm 1,2$ & $<0,25$ \\
\hline Černý potok, O. - Přívoz & $22,60 \pm 1,33$ & $0,153 \pm 0,029$ & $<1,36$ & $95,7 \pm 1,5$ & $<0,25$ \\
\hline Opava, O. - Třebovice & $16,17 \pm 1,04$ & $0,887 \pm 0,055$ & $<1,36$ & $35,2 \pm 1,4$ & $<0,25$ \\
\hline Ostravice, O. - Vítkovice DOV & $<12,5$ & $0,183 \pm 0,006$ & $<1,36$ & $22,5 \pm 1,3$ & $<0,25$ \\
\hline Lučina, O. - Kunčice NH Zářičí & $<12,5$ & $0,804 \pm 0,034$ & $<1,36$ & $88,8 \pm 0,7$ & $0,64 \pm 0,03$ \\
\hline Lučina, Haviŕov pod ČOV & $<12,5$ & $0,171 \pm 0,009$ & $<1,36$ & $22,9 \pm 1,5$ & $<0,25$ \\
\hline
\end{tabular}

Pozn.: Hodnoty v tabulkách 2 a 3 za znakem < jsou pod limity kvantifikace použitých metod. Hodnota limitu kvantifikace dané metody vždy následuje za tímto znakem.

Tabulka 4. Prưměrné hodnoty délky kořenů hořčice bílé (Sinapis alba) a vypočtené procento inhibice (resp. stimulace) rưstu kořene po expozici vodným výluhem reálných vzorků sedimentů

Table 4. Average values of white mustard root length (Sinapis alba) and calculated percentage of root growth inhibition (stimulation) after exposure to aqueous extract of real sediment samples

Vzorek

Artificiální půda (negativní kontrola)

Olše, Třinec

Olše, Dětmarovice

Bohumínská stružka, N. Bohumín

Černý potok, O. - Přívoz

Opava, O. - Třebovice

Ostravice, O. - Vítkovice DOV

Lučina, O. - Kunčice NH Zářičí

Lučina, Havírov pod ČOV

\section{Délka kořene [mm]}

34,401

43,636

43,286

41,304

41,935

43,969

42,581

44,282

39,911
Inhibice [\%]

0

$-27,047$

$-25,801$

$-20,094$

$-22,080$

$-27,817$

$-23,575$

$-28,431$

$-15,938$

\section{Směrodatná odchylka}

0

6,472

3,527

1,109

5,703

6,640

7,243

9,850

8,080 


\section{Ekotoxikologické hodnocení}

Vodné výluhy odebraných vzorků sedimentů připravené podle ČSN EN 12457-4 [21] byly testovány na semenech Sinapis alba a bakteriích Vibrio fischeri. Na základě provedeného testu na Sinapis alba bylo zjištěno, že žádný ze vzorků dnových sedimentů nezpůsoboval inhibici růstu kořene hořčice bílé (Sinapis alba). U všech sledovaných vzorků byla pozorována stimulace, jejiž prưměrná hodnota činila 23,85 \pm 4,04 \%. Průměrné hodnoty délky kořenů hořčice bílé a vypočtené procento stimulace růstu kořene po expozici vodnými výluhy vzorků sedimentů shrnuje tabulka 4.

Pro ověření vhodnosti použití akvatických testů pro hodnocení dnových sedimentů byl proveden druhý akvatický test akutní toxicity na bakteriích Vibrio fischeri. Nejvyšší inhibice luminiscence byla pozorována u vzorku sedimentu pocházející z řeky Lučiny v lokalitě Ostrava, NH Zářičí (33,73 \pm 5,27 \%, Tukey test: $P$-value $=0,0015)$. Na ostatních sledovaných lokalitách vykazovaly vodné výluhy sedimentů inhibici luminiscence v rozmezí 10,593-19,023 \%. Porovnání inhibice luminiscence bakterí Vibrio fischeri mezi jednotlivými vzorky dnových sedimentů je zobrazeno na obr.3.

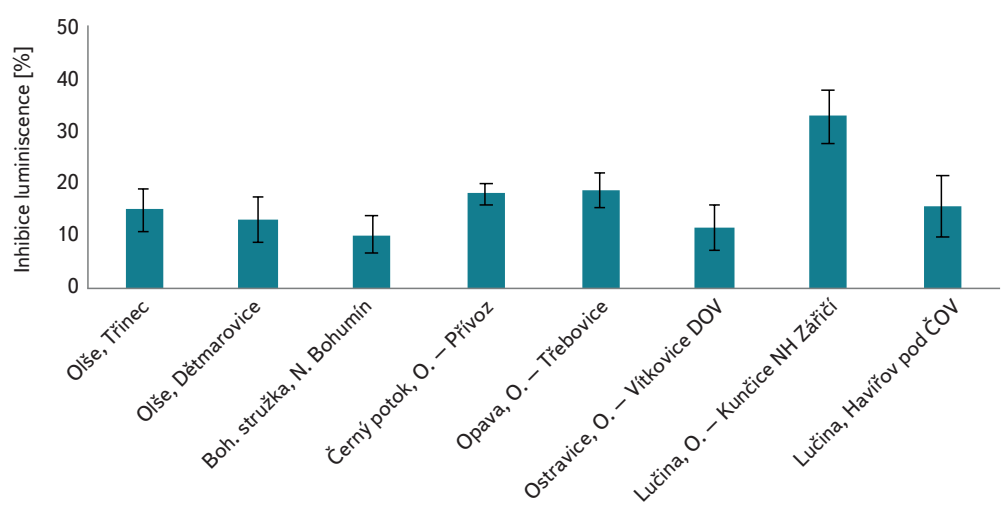

Obr. 3. Porovnání inhibice luminiscence bakterií Vibrio fischeri mezi jednotlivými vzorky dnových sedimentů

Fig. 3. Comparison of luminescence inhibition of Vibrio fischeri bacteria among individual samples of bottom sediments

Na základě dosažených výsledků Ize konstatovat, že akvatické testy využívající vodné výluhy sedimentů jsou méně citlivé a nepotvrdily toxické účinky u vzorků sledovaných sedimentů, popř. indikovaly nízké toxické působení. Testování vzorků sedimentů na semenech hořčice bílé (Sinapis alba) neprokázalo toxický vliv sledovaných vzorků na kličivost a růst semen, naopak byl pozorován stimulační účinek, který byl pravděpodobně způsoben př́tomností nutrientů v sedimentech. Obdobné výsledky uvádějí Czerniawska-Kusza a kol. [30], kteři na vzorcích silně antropogenně znečištěných sedimentů získaných z toku Mlynówka v Opoli naměřili hodnoty stimulace růstu kořene hořčice bílé v rozmezí 20-25\%. Výsledek měření rovněž zdůvodňují pravděpodobnou př́tomností velkého množství živin uložených v sedimentu (sloučeniny dusíku a fosforu), které mohou zcela překrýt inhibiční účinek fytotoxických kontaminantů, a způsobit tak falešně negativní výsledky.

Test akutní toxicity na bakteriích Vibrio fischeri prokázal slabé toxické působení látek př́tomných $v$ sedimentu na všech sledovaných profilech. $V$ současnosti se ve většině prípadů při testování na bakteriích Vibrio fischeri upouští od metody testu ve vodném výluhu. Důvodem je špatná vyluhovatelnost sedimentu, která omezuje možnost přesného stanovení toxikologického indexu $\left(\mathrm{EC}_{50}\right)$. Plně tuto metodu nahrazuje metoda, ve které se testuje účinek suspenze sedimentů. Jarque a kol. [31] uvádějí, že vodné výluhy byly při testování na bakteriích Vibrio fischeri ve srovnání se suspenzemi sedimentů získaných z řeky Moravy a Dřevnice výrazně méně toxické. U výluhů byla 50\% inhibice pozorována jen zř́dka a toxicita mohla být popsána jen jako inhibice luminiscence. Vzhledem k tomuto trendu Bláha [17] doporučuje při novelizaci vyhlášky č. 257/2009 Sb. pro komplexnější stanovení znečištění rozšíritit možnosti testování na bakteriích Vibrio fischeri o nové metody jak kapalných vzorků, tak zavést do české legislativy právě metody testování v suspenzi pevné matrice. Bláha [32] již ve své starší práci poukazuje na neefektivnost akvatických testů ekotoxicity. Podle něj aplikace akvatických testů ve formě, jakou uvádí tabulka č. 10.2 vyhlášky č. 294/2005 Sb. na sedimenty, které byly dlouhodobě exponovány vlivům vodního prostředí, není vždy zcela efektivní. Doporučuje u sedimentů aplikovat spíše kontaktní ekotoxikologické testy na roupicích, chvostoskocích, salátu či použít nitrifikační testy.

Z důvodu nedostatečné vypovídající schopnosti akvatických testů byly pro hodnocení vybraných sedimentů zařazeny kontaktní testy, které nemohou být ovlivněny nízkou vyluhovatelností, a díky tomu jsou považovány za testy o vyšší citlivosti. Zástupcem kontaktních testů pro hodnocení akutní toxicity dnových sedimentů byl test inhibice reprodukce a mortality u chvostoskoků (Folsomia candida). Nejvyšší dosažená hodnota procenta mortality a inhibice reprodukce byla zjištěna u vzorku sedimentu odebraného z Bohumínské stružky v lokalitě Nový Bohumín (mortalita 16,67 $\pm 6,24 \%$, Tukey test: $P$-value $=0,0461$; inhibice reprodukce 39,40 $\pm 13,25 \%$, Tukey test: $P$-value $=0,0011$. Chemická analýza AAS nepotvrdila zvýšený výskyt těžkých kovů v sedimentu získaného z Bohumínské stružky, nicméně vzorek sedimentu obsahoval vysoké koncentrace majoritních kovů ve srovnání s průměrem ostatních vzorků, a to 8,8× více $\mathrm{Ca}$, 2,5× více $\mathrm{Mg}$, $4 \times$ více $\mathrm{Fe}, 7,3 \times$ více $\mathrm{Na}$, které mohly ovlivnit hodnoty mortality a inhibice reprodukce chvostoskoků. Výskyt vysokých koncentrací majoritní kovů v Bohumínské stružce je i v současnosti ovlivněn báňskou činností [33]. Z Vodní jámy Žofie stejnojmenného dolu jsou do Bohumínské stružky čerpány slané důlní vody, pro zabránění přeronu vody do stále funkční části uhelného revíru. Podle zákona č. 44/1988 Sb., o ochraněa využití nerostného bohatství, (Hornízákon) [34] nejsou odčerpané slané důlní vody považovány za odpadní vodu, a proto mohou být rovnou vypouštěny do vodního toku, kde se vysoké koncentrace jinak neškodných solí dostatečně zředí. V prrípadě řeky Lučiny v lokalitě Ostrava, NH Zářičí mohly zvýšení hodnot mortality $(21,67 \pm 9,43 \%$, Tukey test: $P$-value $=0,0041)$ a inhibice reprodukce chvostoskokủ $(24,15 \pm 9,37 \%)$ způsobit relativně vyšší koncentrace kadmia $\left(0,00804\right.$ mg.kg $\left.{ }_{\text {suš }}{ }^{-1}\right)$, zvýšená koncentrace zinku $\left(0,888\right.$ mg.kg $\left.{ }_{\text {sušs }}{ }^{-1}\right)$, či př́tomnost rtuti $\left(0,0064 \mathrm{mg} \cdot \mathrm{kg}_{\text {suš }}{ }^{-1}\right)$. Srovnání mortality a inhibice reprodukce chvostoskoků (Folsomia candida) mezi jednotlivými typy vzorků dnových sedimentů jsou znázorněny na obr. 4.

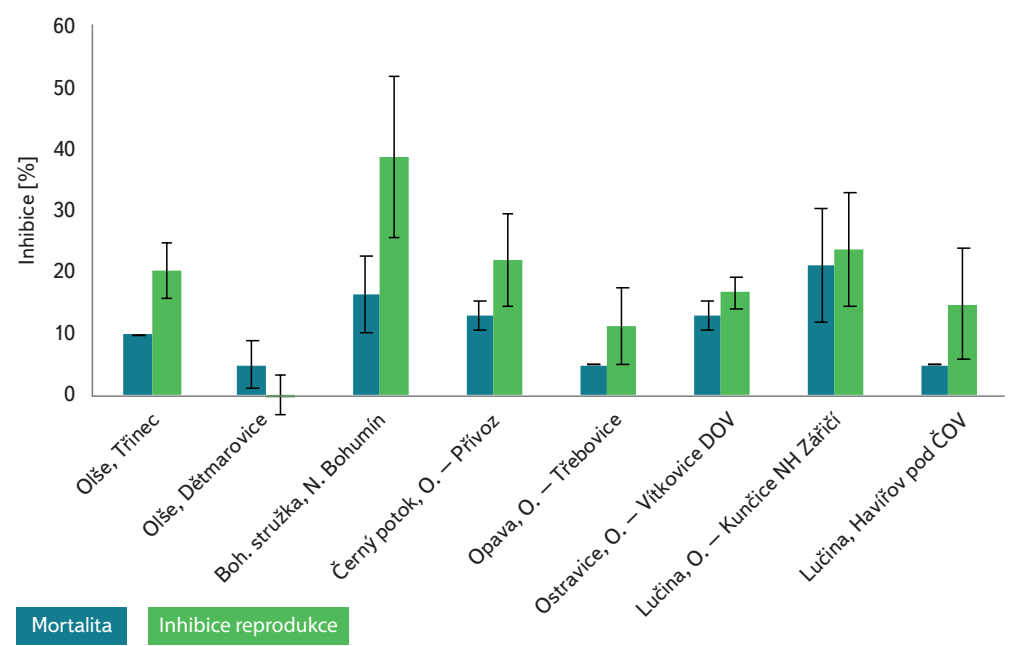

Obr. 4. Srovnání mortality a inhibice reprodukce chvostoskoků (Folsomia candida) mezi jednotlivými typy vzorků dnových sedimentů

Fig. 4. Comparison of Folsomia candida mortality and reproduction inhibition among individual types of bottom sediment samples 
Dalším kontaktním testem využitým pro hodnocení dnových sedimentů byl test akutní toxicity pro stanovení inhibice růstu kořene salátu lociky seté (Lactuca sativa var. capitata). Nejvyšší inhibice růstu kořene byly pozorovány u vzorků sedimentu pocházející z Bohumínské stružky v lokalitě Nový Bohumín $(58,77 \pm 8,78 \%$, Tukey test: $P$-value $<0,0001)$ a řeky Lučiny v lokalitě Ostrava, NH Záričí $(56,91 \pm 9,90 \%$, Tukey test: $P$-value $<0,0001)$. Zvýšená míra inhibice růstu kořene byla pravděpodobně způsobena vyššími koncentracemi majoritních kovů ve srovnání s průměrem ostatních vzorků, a to 8,8× více Ca, 2,5× více Mg, $4 \times$ více $\mathrm{Fe}, 7,3 \times$ více $\mathrm{Na}$, které mohly způsobit zvýšenou inhibici růstu kořene salátu lociky seté (Lactuca sativa var. capitata), obdobně jako v testu s využitím chvostoskoků. Rovněž Fargašová [35] uvádí, že salát locika setá (Lactuca sativa) vykazuje nejvyšší citlivost na těžké kovy a další látky. Srovnání inhibice růstu kořene salátu (Lactuca sativa) mezi jednotlivými typy vzorků dnových sedimentů je zobrazeno na obr. 5 .

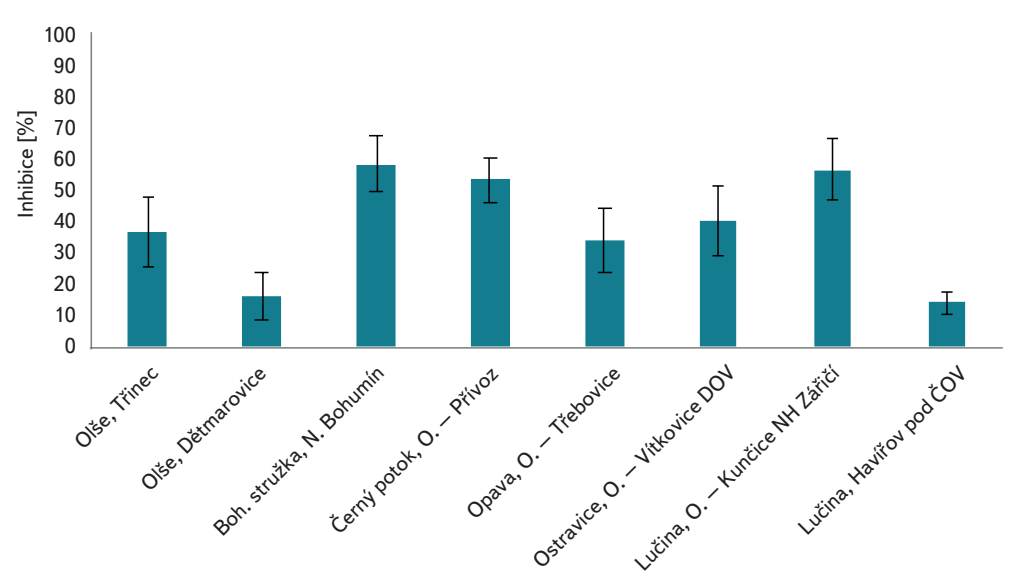

Obr. 5. Srovnání inhibice růstu kořene salátu (Lactuca sativa) mezi jednotlivými typy vzorků dnových sedimentů

Fig. 5. Comparison of lettuce root growth inhibition (Lactuca sativa) among different types of bottom sediment samples

Dalším z baterie vybraných testů byla mikrometoda pro stanovení potenciální nitrifikace provedená podle metodiky uvedené v př́loze B ČSN ISO 15685 [25]. Na základě získaných hodnot absorbance koncentrační řady standardní látky dusitanu sodného při $\lambda=540 \pm 10 \mathrm{~nm}$ byly vypočítány koncentrace dusitanů v jednotlivých vzorcích dnových sedimentů po 2 a 6hodinové inkubaci ve zkušebním médiu. Výpočtem byla stanovena u jednotlivých vzorků potenciální nitrifikace jako koncentrace ng.g $\mathrm{NO}_{2}-\mathrm{N} v$ sušině půdy za hodinu. Nejvyšší hodnota potenciální nitrifikace byla naměřena u vzorku sedimentu pocházející z Bohumínské stružky v lokalitě Nový Bohumín (396,23 \pm 15,08 ng/g NO $-\mathrm{N}$ $\checkmark$ sušině pưdy za hodinu). Nejnižší hodnoty potenciální nitrifikace byly naměřeny u vzorků sedimentů pocházející z řeky Lučiny v lokalitě Ostrava, NH Zářičí (3,19 $\pm 2,05$ ng.g - $^{-1} \mathrm{NO}_{2}-\mathrm{N}$ v sušině půdy za hodinu) a řeky Olše - v lokalitě Třinec, železárny $\left(8,12 \pm 4,84\right.$ ng.g $g^{-1} \mathrm{NO}_{2}-\mathrm{N} v$ sušině půdy za hodinu). Srovnání potenciální nitrifikace mezi jednotlivými typy vzorků dnových sedimentů je uvedeno na obr.6.

Norma ČSN ISO 15685 [25] v tabulce A. 2 uvádí průměrnou referenční hodnotu potenciální nitrifikace neznečištěné referenční půdy jako $540 \mathrm{ng} \cdot \mathrm{g}^{-1} \mathrm{NO}_{2}-\mathrm{N}$ v sušině půdy za hodinu, nižší hodnoty indikují zvýšenou kontaminaci. Vzorky sedimentů vykazující nízké hodnoty potenciální nitrifikace jsou daleko více znečištěné než vzorky, které vykazují vyšší hodnoty. Rovněž půdy obhospodařované ekologickým způsobem bez použití hnojiv, pesticidů a dalších látek, které by mohly způsobit kontaminaci půdy, vykazují vyšší hodnoty potenciální nitrifikace než půdy kontaminované těmito látkami [36]. V př́padě řeky Lučiny v lokalitě Ostrava, NH Zářičí mohla být nízká hodnota potenciální nitrifikace způsobena relativně vyššími koncentracemi kadmia $\left(0,00804 \mathrm{mg} \mathrm{kg}_{\text {suš }}{ }^{-1}\right)$, zvýšenou

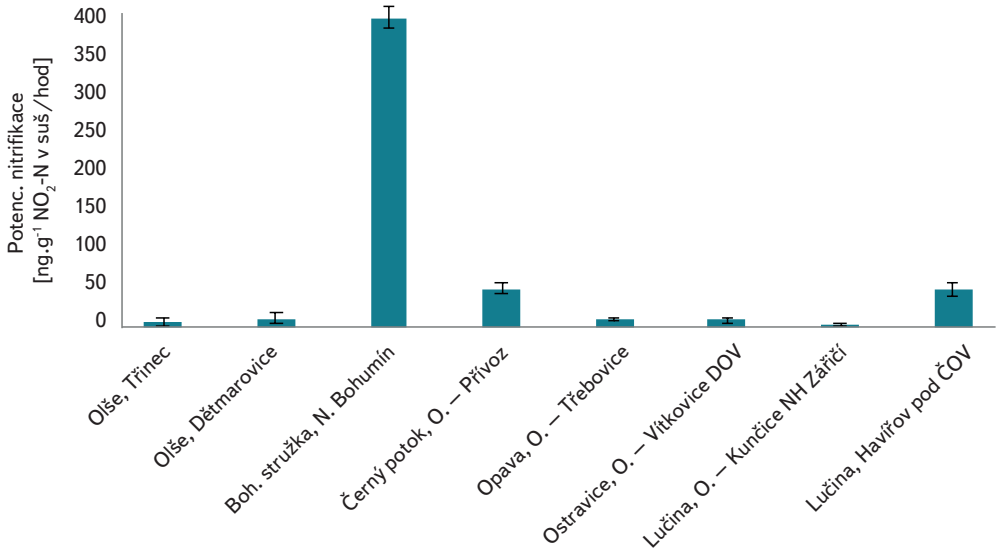

Obr. 6. Srovnání potenciální nitrifikace mezi jednotlivými typy vzorků dnových sedimentů

Fig. 6. Comparison of potential nitrification among individual types of bottom sediment samples

koncentrací zinku $\left(0,888 \mathrm{mg} \cdot \mathrm{kg}_{\text {sušs }}{ }^{-1}\right)$, či prítomností rtuti $\left(0,0064 \mathrm{mg} \cdot \mathrm{kg}_{\text {suš }}{ }^{-1}\right)$. $\checkmark$ prípadě řeky Olše $v$ lokalitě Třinec, železárny mohla být nízká hodnota potenciální nitrifikace způsobena relativně vyššími koncentracemi olova (0,3473 mg.kg $\left.{ }_{\text {suš }}{ }^{-1}\right)$ a kadmia $\left(0,00737\right.$ mg.g $\left.{ }_{\text {suš }}{ }^{-1}\right)$. Jako u jediného vzorku byla zaznamenána prítomnost chromu $\left(0,0481 \mathrm{mg} \cdot \mathrm{kg}_{\text {sušs }}{ }^{-1}\right)$ a zaznamenána byla také ve srovnání s ostatními vzorky nejvyšší koncentrace zinku (1,333 mg.kg $\left.{ }_{\text {suš }}{ }^{-1}\right)$. V obou prípadech také není vyloučena možnost, že na tak nízkých hodnotách potenciální nitrifikace mají vliv př́tomné organické látky.

Na základě naměřených dat, která byla zanesena na obr. 7, Ize sledovat rozdílné hodnoty citlivosti provedených metod. Obecně Ize konstatovat, že nižší citlivost při hodnocení ekotoxických vlastností dnových sedimentů predstavovaly akvatické testy. Nejnižší vypovídající schopnost vykazoval test inhibice růstu kořene hořčice bílé (Sinapis alba). Hodnoty pro svou relativně silnou stimulaci nebyly na obr.7zaneseny. Dále se nízkou vypovídající schopností projevil test na bakteriích Vibrio fischeri, což potvrzuje správnost současného trendu v testování s využitím tohoto testu, kdy se upouští od hodnocení vodných výluhů a přechází se na testování látek v suspenzi [17, 31]. Změna metodiky testu na Vibrio fischeri přináší podstatné zvýšení citlivosti tohoto testu. Výsledky dosažené pomocí kontaktních testů vykazovaly významně zvýšené procento pozorovaného efektu u sledovaných organismů. Nejvyšší negativní odezva, tedy inhibice růstu kořenů, byla pozorována $v$ testu na Lactuca sativa, kdy byla u jednotlivých vzorků dnových sedimentů pozorována inhibice v rozsahu 14,16-58,77 \%. Rovněž výsledky detekované v testu s využitím chvostoskoků Folsomia candida vykazovaly hodnoty reprodukce dosahující téměř $40 \%$ procentní inhibice. Nižší citlivost se projevila u mortality chvostoskoků (Folsomia candida), kdy byla pozorována inhibice pouze do 21,67\%. Zjištění rozdílné citlivosti u těchto dvou sledovaných parametrů v testu na Folsomia candida je v souladu s údaji zjištěnými v literatuře [37], kde je rovněž popisována několikanásobně menší citlivost chvostoskoků $\vee$ ukazateli mortalita než reprodukce. Vhodnou metodou pro hodnocení sedimentů se rovněž jeví stanovení potenciální nitrifikace, pomocí které byl na všech sledovaných lokalitách prokázán negativní vliv indikující zvýšenou kontaminaci. Přehledné výsledky testů akutní toxicity na vybraných indikátorových organismech jsou uvedeny v tabulce 5. Celkově Ize na základě dosažených výsledků konstatovat, že akvatické typy ekotoxikologických testů jsou vzhledem k nižší citlivosti méně vhodné pro stanovování ekotoxických účinků dnových sedimentů. Testování by mělo být prováděno prioritně na kontaktních testech, které poskytují spolehlivější informace o znečištění sedimentu $\checkmark$ dané lokalitě.

Vyhodnocení negativního efektu zaznamenaného $v$ jednotlivých testech akutní toxicity u vzorků sedimentů ze sledovaných lokalit je zobrazeno 
v tabulce 5 a obr. 8. Nejvíce znečištěné dnové sedimenty se nacházely v lokalitách Bohumínská stružka - Nový Bohumín, Lučina - NH Záričí a Černý potok Ostrava-Přivoz. Na ostatních sledovaných profilech vykazovaly odebrané dnové sedimenty ve většině využitých testů slabý toxický efekt, a tedy představují potenciálně zanedbatelné riziko pro sledované indikátorové organismy.

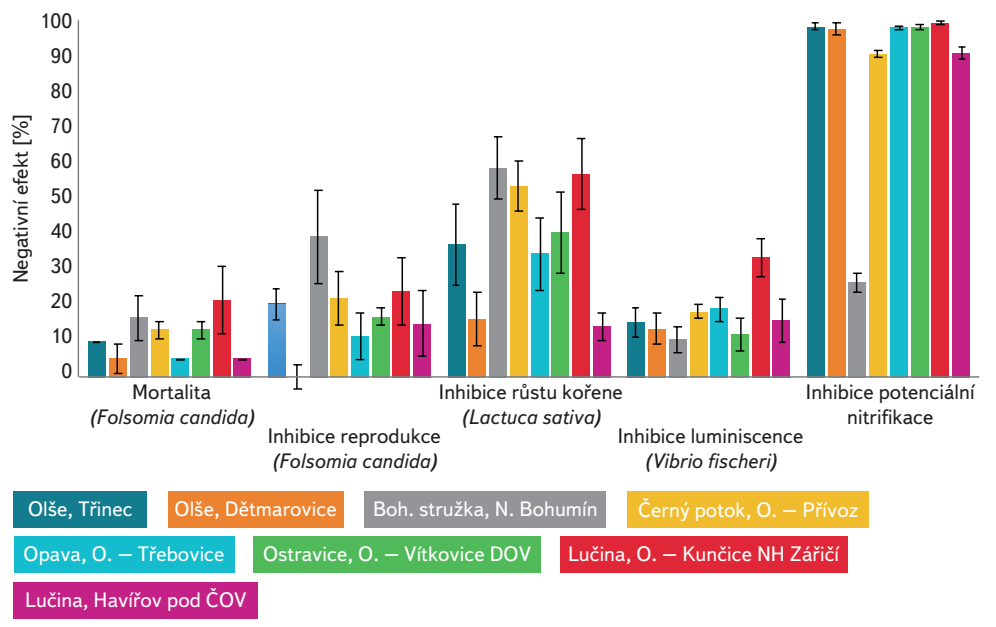

Obr. 7. Srovnání citlivosti jednotlivých ekotoxikologických testů Fig. 7. Sensitivity comparison of individual ecotoxicological tests

\section{ZÁVĚR}

V rámci monitoringu znečištění vodního prostředí je potřeba sledovat nejen jakost vody, ale i stav dnových sedimentů. Sedimenty na své částice sorbují polutanty anorganické a organické povahy, které se akumulují a mohou se při skokové změně podmínek $v$ daném toku uvolnit do vody, a ohrozit tak celý ekosystém.

$\checkmark$ rámci hodnocení toxického působení dnových sedimentů na okolní ekosystém byla provedena baterie pěti ekotoxikologických testů na vzorcích odebraných na vodních tocích v rámci povodí řeky Odry. Na základě provedených kontaktních testů bylo stanoveno, že sedimenty z Bohumínské stružky odebrané v lokalitě Nový Bohumín a řeky Lučiny v lokalitě NH Zářičí predstavují

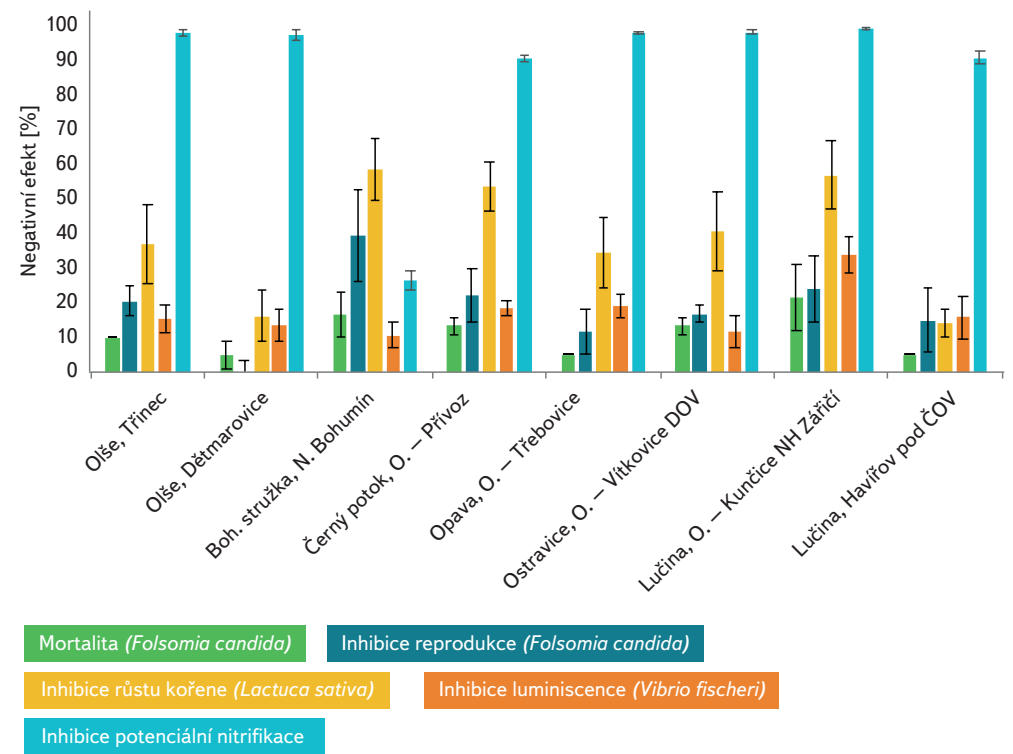

Obr. 8. Srovnání negativního efektu pozorovaného v testech akutní toxicity u vzorků sedimentů z jednotlivých lokalit

Fig. 8. Comparison of the negative effect observed in acute toxicity tests on sediment samples from individual localities

vzorky s vyšším toxickým zatížením. Látky navázané v těchto sedimentech mohou po uvolnění do vody ohrozit ekosystém dané lokality. Na ostatních sledovaných lokalitách bylo pozorováno mírnější toxické působení na indikátorové ekotoxikologické organismy. V testech využivajících vodné výluhy sedimentů bylo potvrzeno, že citlivost a vypovídající hodnota těchto testů využívaných pro hodnocení sedimentů je velmi nízká v porovnání s kontaktními testy.

Ze zjištěných výsledků vyplývá, že pro komplexnější ekotoxikologické zhodnocení dnových sedimentů je potřeba vždy využívat baterii testů s organismy různých trofických úrovní s preferencí využití kontaktních testů před akvatickými testy hodnotícími vodné výluhy sedimentů. Ekotoxikologické sledování je vhodné doplnit chemickou analýzou pro kvalitativní a kvantitativní stanovení těžkých kovů a organických látek. Tyto analýzy poskytují cenné informace pro vysvětlení účinků daného vzorku sedimentu na testovaný organismus.

Tabulka 5. Souhrnné výsledky z testů akutní toxicity na vybraných indikátorových organismech; toxický efekt (+), žádný toxický efekt (-), slabý toxický efekt (+/-) Table 5. Summary of results of acute toxicity tests using chosen indicator organisms; toxic effect (+), no toxic effect (-) weaker toxic effect (+/)

\begin{tabular}{|c|c|c|c|c|c|c|}
\hline Vzorek & $\begin{array}{l}\text { Sinapis } \\
\text { alba [\%] }\end{array}$ & $\begin{array}{l}\text { Vibrio } \\
\text { fischeri [\%] }\end{array}$ & $\begin{array}{l}\text { Folsomia } \\
\text { candida } \\
\text { Mortalita [\%] }\end{array}$ & $\begin{array}{l}\text { Folsomia } \\
\text { candida } \\
\text { Reprodukce [\%] }\end{array}$ & $\begin{array}{l}\text { Potenciální nitrifikace } \\
{\left[\text { ng.g }^{-1} \mathrm{NO}_{2}-\mathrm{N} \text { v suš./h] }\right.}\end{array}$ & $\begin{array}{l}\text { Lactuca } \\
\text { sativa [\%] }\end{array}$ \\
\hline Olše, Třinec & - & $+/-$ & $+/-$ & + & + & + \\
\hline Olše, Dětmarovice & - & $+/-$ & - & - & $+/-$ & $+/-$ \\
\hline Bohumínská stružka, N. Bohumín & - & $+/-$ & $+/-$ & + & + & + \\
\hline Černý potok, O. - Přívoz & - & $+/-$ & $+/-$ & + & + & + \\
\hline Opava, O. - Třebovice & - & $+/-$ & - & $+/-$ & + & + \\
\hline Ostravice, O. - Vítkovice DOV & - & $+/-$ & $+/-$ & $+/-$ & + & + \\
\hline Lučina, O. - Kunčice NH Zářičí & - & + & + & + & + & + \\
\hline Lučina, Haviŕrov pod ČOV & - & $+/-$ & - & $+/-$ & + & $+/-$ \\
\hline
\end{tabular}




\section{Literatura}

[1] ČERNÝ, M. a JEDLIČKA, M. Hydrologická ročenka České republiky 2017: III. HYDROLOGICKÁ BILANCE JAKOSTI VODY [online]. Praha: Český hydrometeorologický ústav, 2018 [cit. 2020-06-20]. ISBN 978-8087577-86-8. Dostupné z: http://voda.chmi.cz/pdf/kap3.pdf

[2] KIZLINK, J. Odpady: sběr, zpracování, zužitkování, zneškodnění, legislativa [online]. Brno: CERM, 2014. ISBN 978-80-7204-884-7.

[3] ODUKOYA, A. and AKANDE, O. Metal contamination assessment in the urban stream sediments and tributaries of coastal area southwest Nigeria. Chinese Journal of Geochemistry [online], 2015, Vol. 34 . No. 3, p. 431-446. Dostupné z: doi:10.1007/s11631-014-0027-1

[4] DE CASTRO-CATALA, N. Ecotoxicity of sedimetns in rivers: Invertebrate community, toxicity bioassays and the toxic unit approach as complementary assessment tools. Science of the Total Environment [online]. 2016, č. 540, s. 297-306. ISSN 00489697. Dostupné z: doi: 10.1016/ j.scitotenv.2015.06.071

[5] BENEŠOVÁ, L. a HNAŤUKOVÁ, P. Možnosti použití dnových sedimentů do zemědělských půd. EnviGroup [online]. 2009 [cit. 2020-03-03]

[6] PITTER, P. Hydrochemie [online]. 5. aktualizované a doplněné vydání. Praha: Vysoká škola chemickotechnologická v Praze, 2015

[7] GALIA, T. Fluviální geomorfologie [online]. Ostrava: Ostravská univerzita, Prírodovědecká fakulta, katedra fyzické geografie a geoekologie, 2017. ISBN 978-807-4649-011.

[8] KRAUS, F. Znečištění pražských vodních toků a vodních ploch těžkými kovy: Zpráva zpracovaná $\checkmark$ rámci projektu „Oživení pražských vod" Arnika [online]. 2017 [cit. 2020-03-03].

[9] DEVESA-REY, IGLESIAS, R.M., and PÉREZ-MOREIRA, R. Application of the Weng's ratio for the identification of $\mathrm{Zn}, \mathrm{Cu}$ and $\mathrm{Pb}$ contamination on soils and sediments,. Journal of Soils and Sediments [online], 2013, Vol. 13, No. 5, p. 932-942.

[10] MOUKCHAN, F., MARCH, J., and CERDA, V. Distribution of trace metals in marine sediments of the Bay of Palma de Mallorca (Mallorca Island, Spain). Environmental Monitoring and Assessment [online], 2013, Vol. 185, No. 1, p. 695-706.

[11] KOWALSKA, M., GÜLER, H., and COCKE, D. Interactions of clay minerals with organic pollutants. Science of the Total Environment [online], 1994, Vol. 141, No. 1-3, p. 223-240. Dostupné z: doi: 10.1016/0048-9697(94)90030-2

[12] HUCKO, P. Legislatívne hodnotenia sedimentov vodných tokov s nádrží v SR. In: Analytika odpadů II [online]. Ždár nad Sázavou: EKOMONITOR spol. s.r.o., 2012, s. 83-90. ISBN 9788086832692.

[13] SHIMIZU, Y., YAMAZAKI, S., and TERASHIMA, Y. Sorption of Anionic Pentachlorophenol (PCP) in Aquatic Environments: The Effect of pH. Water Science and Technology [online], 1992, Vol. 25, No. 11, p. 41-48. ISSN 0273-1223. Dostupné z: doi:10.2166/wst.1992.0271

[14] JOHNSON, W. and AMY, G. Facilitated Transport and Enhanced Desoption of Polycyclic Aromatic Hydrocarbons by Natural Organic Matter in Aquifer Sediments. Environmental Science and Technology [online]. 2002, vol, 29, No. 3, p. 807-817. Dostupné z: doi:10.1021/es00003a032

[15] HUBALOVÁ, P. a JANÍČEK, T. Zpráva o stavu vodního hospodárství České republiky v roce 2018 [online]. Praha: Ministerstvo zemědělství České republiky, 2019 [cit. 2020-06-21]. ISBN 978-80-7434-523-4. Dostupné z: http://eagri.cz/web/file/64073/Modra_zprava_2018_web.pdf

[16] CHAPMAN, P. and HO, K. Issues in sediment toxicity and ecological risk assessment. Marine Pollution Bulletin [online], 2002, Vol. 44, No. 4, p. 271-278.

[17] BLÁHA, V. Aplikace ekotoxikologických testů, testy na reálných vzorcích. In: Sedimenty z vodních toků a nádrži [online]. Hradec Králové: EMPLA spol. s r. 0., 2018, s. 90-92. ISBN 978-80-906306-5-9.

[18] ČSN ISO 5667-12: Jakost vod - Odběr vzorků - část 12: Návod pro odběr vzorků dnových sedimentů z rek, jezer a zoblastí ústí rek. Úřad pro technickou normalizaci, metrologii a státní zkušebnictví, 2018.

[19] ČSN ISO 10390: Kvalita půdy - StanovenípH. Úřad pro technickou normalizaci, metrologii a státní zkušebnictví, 2011.

[20] ČSN ISO 11274: Kvalita půdy - Stanoveni retenčních vlhkostních charakteristik - Laboratorni metody. Úřad pro technickou normalizaci, metrologii a státní zkušebnictví, 2020.

[21] ČSN EN 12457-4: Charakteristika odpadů - Vyluhování - Ověřovací zkouška vyluhovatelnosti zrnitých odpadů a kalů - Část 4: Jednostupňová vsádková zkouška při poměru kapalné a pevné fáze $10 \mathrm{l} / \mathrm{kg}$ pro materiály se zrnitostí menší než $10 \mathrm{~mm}$ (bez zmenšení velikosti částic, nebo s ním) [online]. Úřad pro technickou normalizaci, metrologii a státní zkušebnictví, 2013.

[22] Metodický pokyn odboru odpadů ke stanovení ekotoxicity odpadů. Praha: Ministerstvo životního prostředí České republiky, 2007.

[23] ČSN EN ISO 11348-1: Jakost vod - Stanovení inhibičního účinku vzorků vod na světelnou emisu Vibrio fischeri (Zkouška na luminiscenčních baktérích) - Část 1: Metoda s čerstvě pripravenými bakteriemi. Úřad pro technickou normalizaci, metrologii a státní zkušebnictví, 2009.

[24] ČSN EN ISO 11267 - Kvalita půdy - Inhibice reprodukce chvostoskoků (Folsomia candida) látkami znečištujićími pưdu. Úrad pro technickou normalizaci, metrologii a státní zkušebnictví, 2014

[25] ČSN ISO 15685: Kvalita půdy - Stanovení potenciální nitrifikace a inhibice nitrifikace - Rychlá zkouška pomocí oxidace amonných iontů [online]. Úrad pro technickou normalizaci, metrologii a státní zkušebnictví, 2014.
[26] Standardní operační procedura SOILETOX_SOP_20: Test ekotoxicity se salátem Lactuca sativa [online]. 1.0.RECETOX. 2010

[27] Spravované lokality. Diamo, s. p. [online]. [cit. 2020-09-24]. Dostupné z: https.//www.diamo.cz/cs/ spravovane-lokality/odra/all/50

[28] Nařízení vlády č. 401/2015 Sb.: Nařizení vlády o ukazatelích a hodnotách přípustného znečištění povrchových vod a odpadních vod, náležitostech povolení k vypouštění odpadních vod do povrchových vod a do kanalizací a o citlivých oblastech, 2015.

[29] Vyhláška č. 70/2018 Sb.: Vyhláška, kterou se mění vyhláška č. 252/2004 Sb., kterou se stanoví hygienické požadavky na pitnou a teplou vodu a četnost a rozsah kontroly pitné vod, ve znění pozdějších předpisư, 2018 .

[30] CZERNIAWSKA-KUSZA, I. CIESIELCZUK, T., KUSZA, G., and CICHON, A. Comparison of the Phytotoxkit microbiotest and chemical variables for toxicity evaluation of sediments. Environmental Toxicology [online], 2006, Vol. 21, No. 4, p. 367-372. Dostupné z: doi:10.1002/tox.20189

[31] JARQUE, S., MASSNER, P., KLÁNOVÁ, R., PROKEŠ, R., and BLÁHA, L. Bioluminiscent Vibrio fischeri Assays in the Assessment of Seasonal and Spatial Patterns in Toxicity of Contaminated River Sediments. Frontiers in Microbiology [online], 2016, Vol. 7, p. 1-11. Dostupné z: doi:10.3389/fmicb.2016.01738

[32] BLÁHA, V. Nejasnosti kolem sedimentů. Odpadovéfórum [online], 2011, č. 2, s. 15-16.

[33] Stružka. In: Atlas hlavních vodních toků povodíOdry [online]. Povodí Odry, s. p., 2016 [cit. 2020-06-20]. Dostupné z: https://www.pod.cz/atlas_toku/struzka.html

[34] Zákon č. 44/1988Sb: o ochraně a využití nerostného bohatství (Horní zákon), 1988.

[35] FARGAŠOVÁ, A. Ekotoxikologické biotesty [online]. Bratislav: Perfekt, 2009. ISBN 978-80-8046-422-6.

[36] STŘALKOVÁ, R. a KROFTA, S. Rozdíly potenciální nitrifikace v ornici při pěstování pšenice a ječmene $\checkmark$ konvenčním a ekologickém systému hospodaření. Obilnářské listy [online]. 2009, č. 3, s. 79-81 [cit.2020-06-20]. Dostupné z: https://www.vukrom.cz/userfiles/obilnarske_listy/2009/2009_3/79_81. pdf

[37] KROGH, P. Toxicity testing with the collembolans Folsomia fimetaria and Folsomia candida and the results of a ringtest [online]. 2008 [cit. 2020-07-04].

\section{Autoři}

Mgr. Antonín Vondrák ${ }^{1}$

凶antonin.vondrak@seznam.cz

ORCID: 0000-0002-2832-9399

Mgr. Hana Sezimová, Ph.D. ${ }^{1}$

凶hana.sezimova@osu.cz

ORCID: 0000-0001-6115-2217

Mgr. Martin Mucha, Ph.D. ${ }^{2}$

凶martin.mucha@osu.cz

ORCID: 0000-0003-4748-7488

'Katedra biologie a ekologie PřF, Ostravská univerzita

${ }^{2}$ Katedra chemie PřF, Ostravská univerzita

Příspěvek prošel lektorským řizením.

DOI: 10.46555/VTEI.2020.10.004 


\section{ECOTOXICOLOGICAL EVALUATION OF \\ RIVER SEDIMENTS IN SELECTED LOCAL- ITIES OF THE ODRA RIVER BASIN}

\section{VONDRAK, A. ${ }^{1}$; SEZIMOVA, H. ${ }^{1} ;$ MUCHA, M. ${ }^{2}$}

'Department of Biology and Ecology, Faculty of Science, University of Ostrava ${ }^{2}$ Department of Chemistry, Faculty of Science, University of Ostrava

Keywords: ecotoxicology - sediments - Odra river basin - contamination - hydrochemistry - legislation battery of tests - potential nitrification - Sinapis albaFolsomia candida - Lactuca sativa - Vibrio fischeri

The paper deals with the issue of pollution of river (bottom) sediments in the Odra river basin, which is located in one of the most anthropogenically polluted areas of the Czech Republic. The presented results are based on the evaluation of river sediments collected on eight selected profiles of water bodies belonging to the Odra river basin using a battery of five ecotoxicological tests including indicator organisms of different trophic levels. Ecotoxicological evaluation of sediments was performed by contact tests and on aqueous extracts of sediments using aquatic tests. For determination of acute toxicity, test using Folsomia candida, germination and growth inhibition test using seeds of Sinapis alba, growth inhibition test using Lactuca sativa, luminescence test using bacteria Vibrio fischeri and potential nitrification and inhibition of nitrification determination were used. Monitoring was supplemented by quantitative analysis of major and heavy metals from stabilized aqueous extracts of bottom sediment samples using the method of atomic absorption spectrometry. As part of the evaluation, the sensitivity of individual tests was compared and an analysis of the toxic load of sediments from individual monitored localities was performed. Based on the achieved results, it can be stated that the sediments taken from the Bohumínská stružka and the Lučina river showed the highest toxic load. It has also been confirmed that the predictive value of aquatic ecotoxicological tests is very low and contact ecotoxicological tests are appropriate for sediment testing. 